\title{
NILAI EKONOMI TOTAL PERKEBUNAN KELAPA DI DESA SELUMBUNG, KECAMATAN MANGGIS, KABUPATEN KARANGASEM
}

\section{Total Economic Value of Coconut Plantation at the Selumbung Village, Manggis District, Karangasem Regency}

\author{
Ni Luh Made Indah Murdyani Dewi, I Wayan Budiasa, I Nyoman Gede Ustriyana \\ Program Studi Magister Agribisnis, Fakultas Pertanian, Universitas Udayana, Bali, Indonesia
}

Email: murdyanidewi@gmail.com

\begin{abstract}
Total Economic Value (TEV) of coconut plantation is the total obtained from direct use value, indirect use value, option use value, and existence use value. This study aims to find out potential coconut trees used as wood of a beam and counting total economic value of the existence coconut plantation at Selumbung Village, Manggis District, Karangasem Regency. A descriptive-quantitative method based on TEV was used in this research. Primary data collected by using a survey method to 30 samples of farmers to obtain data on direct use value, option use value and existence use value. Secondary data were collected through literature study to obtain indirect use value. Research result indicates that potential value of coconut wood is IDR 470,435,250.00 per year from the total area of 330.13 ha based on assumption of cut down trees cycle for the coconut tree aged at 100 years. Next, TEV of coconut plantation is IDR 11,975,383,877.76 consisting of IDR 5,140,940,181.36 (42.93\%) direct use value, IDR 3,458,111,750.00 (28.88\%) indirect use value, IDR 3,136,108,890.34 (26.19\%) option use value, and IDR 240,223,056.06 (2.00\%) existence use value. The TEV is about 25.5 times larger than the wood logging potential value. Accordingly, the coconut plantation is better kept and managed by fertilizing to get optimum results.
\end{abstract}

Keyword: direct use value, indirect use value, option use value, existence use value, coconut plantation

\begin{abstract}
ABSTRAK
Total Economic Value (TEV) perkebunan kelapa adalah total yang diperoleh dari nilai penggunaan langsung, nilai penggunaan tidak langsung, nilai penggunaan opsi, dan nilai penggunaan eksistensi. Penelitian ini bertujuan untuk mengetahui pohon kelapa potensial yang digunakan sebagai kayu balok dan menghitung total nilai ekonomi keberadaan perkebunan kelapa di Desa Selumbung, Kecamatan Manggis, Kabupaten Karangasem. Metode deskriptif kuantitatif berdasarkan TEV digunakan dalam penelitian ini. Data primer dikumpulkan dengan menggunakan metode survei sampai 30 sampel petani untuk mendapatkan data nilai pakai langsung, nilai pakai opsi dan nilai pakai eksistensi. Data sekunder dikumpulkan melalui studi pustaka untuk mendapatkan nilai penggunaan tidak langsung. Hasil penelitian menunjukkan bahwa nilai potensial kayu kelapa adalah Rp 470.435.250,00 per tahun dari total luas 330,13 ha berdasarkan asumsi siklus pohon tebang untuk pohon kelapa berumur 100 tahun. Selanjutnya, TEV perkebunan kelapa adalah IDR 11.975.383.877,76 yang terdiri dari nilai pakai langsung IDR 5,140,940,181.36 (42,93\%), nilai manfaat tidak langsung IDR 3,458,111,750,00 (28,88\%), nilai opsi penggunaan IDR 3,136,108,890.34 (26,19\%) dan penggunaan sebesar Rp 240,223,056,06 (2,00\%). nilai. TEV sekitar 25,5 kali lebih besar dari nilai potensi penebangan kayu. Dengan demikian, perkebunan kelapa lebih baik disimpan dan dikelola dengan pemupukan untuk mendapatkan hasil yang optimal.
\end{abstract}

Kata kunci: nilai pakai langsung, nilai penggunaan tidak langsung, nilai penggunaan opsi, nilai keberadaan penggunaan, perkebunan kelapa

\section{PENDAHULUAN}

\section{Latar Belakang}

Tanaman kelapa ditanam hampir di seluruh wilayah Bali. Sentra produksi kelapa terletak di Kabupaten
Jembrana, Karangasem, dan Tabanan. Kabupaten Karangasem memiliki luas areal Tanaman Belum Menghasilkan (TBM) terluas di seluruh Bali yaitu 3.320,38 ha (Disbun, 2016). Hal ini berarti tanaman kelapa di Kabupaten Karangasem memiliki potensi 
untuk terus dikembangkan sehingga nantinya petani yang berada di Kabupaten Karangasem ini dapat memanfaatkan kebun kelapanya untuk terus dilakukan suatu pengembangan. Selain memiliki luas kebun kelapa yang cukup tinggi, produksi kelapa di Kabupaten Karangasem rendah dibandingkan dengan Kabupaten Jembrana dan Tabanan, sehingga perlu adanya peningkatan pemeliharaan untuk mencapai hasil produksi yang maksimal.

Desa Selumbung memiliki perkebunan kelapa seluas 330,13 ha. Tanaman Menghasilkan (TM) seluas 300 ha, sedangkan Tanaman Belum Menghasilkan (TBM) seluas 30,13 ha. Jumlah produksi kelapa dalam bentuk kopra di Desa Selumbung sebesar 295,5 ton, sehingga produktivitasnya diketahui sebesar $985 \mathrm{~kg} / \mathrm{ha} / \mathrm{th}$ kopra. Tanaman kelapa pada satu kilogram kopra memanfaatkan 2,5 butir kelapa. Potensi kelapa dalam satu hektar sebanyak 2462,5 butir/tahun. (UPTD, 2015).

Perkebunan kelapa selain memiliki nilai tangible (berwujud) yang secara nyata dapat menghasilkan devisa bagi negara, juga memiliki nilai-nilai intangible (tidak berwujud) yang belum dihitung secara ekonomi. Sebagai contoh manfaat tanaman kelapa sebagai penyangga bukit-bukit agar tidak terjadi longsor dan nilai kemauan petani dalam membeli dan menggunakan pupuk organik. Sifatnya yang non market tersebut menyebabkan banyak manfaat sumber daya kebun kelapa belum dinilai secara memuaskan dalam perhitungan ekonomi (Iqbal, 2014).

Perkebunan kelapa sudah sejak lama dikenal masyarakat sebagai tanaman yang bernilai ekonomi, namun pola pemanfaatan kebun ini masih sangat rendah, dan masyarakat sekitar belum optimal dalam memanfaatkan dan memelihara kebun kelapa yang ada. Oleh karena itu, perlu dilakukan penelitian tentang $T E V$ terhadap perkebunan kelapa, untuk memberikan informasi mengenai nilai manfaat perkebunan kelapa secara keseluruhan pada Desa Selumbung, Kecamatan Manggis, Kabupaten Karangasem.

Salah satu kunci keberhasilan untuk meningkatkan produktivitas padi petani melalui program tersebut adalah keterlibatan pihak atau lembaga penyuluhan yang berada di pusat maupun di daerah. Peran penyuluh pertanian adalah keterlibatan sebagai penghubung antara dunia ilmu dan pemerintah serta penghubung antara dunia penelitian dengan usaha petani dan keluarganya sehingga akan menggerakkan swadaya masyarakat. Salah satu bentuk dalam pengembangan sumberdaya manusia (SDM) pertanian yang menentukan keberhasilan pengembangan program-program pembangunan pertanian adalah penyuluhan pertanian karena berkaitan langsung dengan petani sebagai pelaku utama dan pelaku usaha lainnya (Wahjuti, 2007).
Keberhasilan program PTT merupakan indikasi baiknya kinerja penyuluh pertanian dalam menjalankan tupoksi penyuluhan yang dilihat dari perilaku (pengetahuan, sikap dan ketrampilan) petani pada penerapan teknologi PTT, dan perilaku petani akan meningkatkan produktivitas padi sesuai dengan potensi wilayahnya. Indikasi tersebut belum dijelaskan secara nyata karena belum adanya kegiatan evaluasi terhadap penyuluh pertanian. Perilaku petani terhadap penerapan teknologi PTT perlu diidentifikasi untuk meyakinkan bahwa paket teknologi tersebut dapat diterima dan meningkatkan produktivitas usahatani petani.

\section{Rumusan Masalah}

Berdasarkan latar belakang di atas, dapat dirumuskan masalah sebagai berikut: (1) Seberapa besar nilai potensi kayu kelapa di Desa Selumbung, Kecamatan Manggis, Kabupaten Karangasem jika ditebang secara keseluruhan? (2) Seberapa besar nilai ekonomi total perkebunan kelapa di Desa Selumbung, Kecamatan Manggis, Kabupaten Karangasem?

\section{Tujuan Penelitian}

Tujuan dari penelitian ini adalah sebagai berikut: (1) Besarnya nilai potensi kayu kelapa di Desa Selumbung, Kecamatan Manggis, Kabupaten Karangasem jika ditebang secara keseluruhan (2) Besarnya nilai ekonomi total perkebunan kelapa di Desa Selumbung, Kecamatan Manggis, Kabupaten Karangasem.

\section{KAJIAN PUSTAKA}

\section{Nilai Potensi Kayu Kelapa}

Analisis volume tegakan dilakukan untuk mengetahui besar dari volume kayu yang ada. Mendapatkan volume kayu, harus diketahui terlebih dahulu nilai dari tinggi dan diameter pohon yang menjadi sampel, kemudian kayu tersebut dipilah sesuai kualitasnya. Analisis volume tegakan tersebut kemudian akan dimasukkan ke dalam notasi perhitungan nilai potensi kayu.

\section{Nilai Ekonomi Total Perkebunan Kelapa}

Menurut Alam, dkk (2009) Nilai ekonomi total adalah keseluruhan nilai yang dimanfaatkan untuk mendapatkan keuntungan yang lebih tinggi. Nilai manfaat total merupakan penjumlahan seluruh nilai ekonomi dari manfaat kebun kelapa yang telah diidentifikasi dan dikuantifikasi. Persamaan yang digunakan dalam menghitung nilai ekonomi total adalah sebagai berikut.

$$
T E V=D U V+I U V+O U V+E U V
$$


di mana:

$\begin{aligned} T E V & =\begin{array}{l}\text { Nilai Total Ekonomi (Total } \\ \text { Economic Value })\end{array} \\ \text { Nilai manfaat langsung (Direct Use } & \text { Value) } \\ \text { NUV } & =\begin{array}{l}\text { Nilai manfaat tidak langsung } \\ \text { Indirect Use Value) }\end{array} \\ \text { Nilai manfaat pilihan (Option Use } & \begin{array}{l}\text { Value) } \\ \text { Nilai manfaat keberadaan } \\ \text { Existance Use Value) }\end{array}\end{aligned}$

Nilai Ekonomi Total dapat dibagi menjadi nilai manfaat langsung, manfaat tidak langsung, nilai pilihan, dan nilai keberadaan. Berikut adalah penjelasan masing-masing manfaat tersebut.

a. Nilai Manfaat Langsung (Direct Use Value/ DUV)

Nilai manfaat langsung adalah nilai yang dihasilkan dari pemanfaatan secara langsung dari suatu sumberdaya. Manfaat langsung bisa diartikan manfaat yang dapat dikonsumsi.

b. Nilai Manfaat Tidak Langsung (Indirect Use Value/ IUV)

Manfaat tidak langsung adalah nilai manfaat dari suatu sumberdaya pohon kelapa yang dimanfaatkan secara tidak langsung oleh masyarakat.

c. Nilai Manfaat Pilihan (Option Value / OUV)

Nilai pilihan untuk perkebunan kelapa biasanya menggunakan metode benefit transfer, yaitu dengan cara menilai perkiraan benefit dari tempat lain (di mana sumberdaya tersedia) lalu benefit tersebut ditransfer untuk memperoleh perkiraan yang kasar mengenai manfaat dari lingkungan (Fauzi, 1999). Metode tersebut didekati dengan cara menghitung besarnya nilai keanekaragaman hayati (nilai biodiversity) yang ada pada ekosistem tersebut.

d. Nilai Manfaat Keberadaan (Existence Use Value/EUV)

Nilai keberadaan yaitu nilai kepedulian seseorang akan keberadaan suatu sumberdaya alam. Nilai manfaat keberadaan sumber daya kebun Kelapa Dalam ini menggunakan pendekatan WTP (Willingness to Pay) yaitu kesediaan petani membayar agar kebun kelapa terpelihara dengan baik.

\section{KERANGKA KONSEP PENELITIAN}

Desa selumbung merupakan salah satu desa yang berada di Kecamatan Manggis dengan memiliki lahan perkebunan kelapa seluas 330,13 hektar. Metode penelitian ini menggunakan analisis nilai total ekonomi dan analisis nilai potensi kayu Kelapa Dalam. Analisis nilai potensi kayu menggunakan perhitungan volume kayu yang kemudian dimasukkan ke dalam notasi perhitungan nilai potensi kayu dengan asumsi umur pohon kelapa yang dapat dijadikan kayu balok adalah 100 tahun.
Analisis nilai ekonomi total dicari dengan menjumlahkan nilai dari manfaat langsung, tidak langsung, pilihan, dan keberadan. Berdasarkan kedua analisis tersebut, diperoleh perbandingan apakah pohon kelapa lebih baik dipertahankan atau ditebang.

\section{METODE PENELITIAN}

\section{Lokasi dan Waktu Penelitian}

Penelitian ini dilaksanakan di Desa Selumbung, Kecamatan Manggis, Kabupaten Karangasem pada Bulan Oktober-Desember 2016. Pemilihan lokasi dilakukan dengan metode purposive yaitu metode penentuan lokasi penelitian yang dilakukan secara sengaja dengan pertimbangan bahwa minyak kelapa di Desa Selumbung merupakan kualitas kelapa yang baik dengan memiliki asam laurit 52,11\% (BPTP, 2006) dan pada tahun 2011 Desa Selumbung pernah meraih juara I lomba desa terpadu tingkat Kecamatan Manggis (Sepel, 2012).

\section{Data, Sampel, dan Analisis Data}

Data Primer yang diperlukan pada penelitian ini adalah data jumlah produksi kelapa dan manfaat lainnya, nilai jual kelapa dan produk lainnya, serta struktur dan keadaan topografi Desa Selumbung dengan metode survei terhadap 30 sampel petani. Data sekunder dikumpulkan dengan studi pustaka seperti manfaat tidak langsung dan hal-hal yang terkait dengan penelitian ini baik melalui buku, jurnal, maupun website. Analisis data yang digunakan ada dua yaitu (1) Nilai potensi kayu Kelapa Dalam jika ditebang secara keseluruhan, (2) Nilai ekonomi total perkebunan Kelapa Dalam.

\section{HASIL DAN PEMBAHASAN}

\section{Nilai Potensi Kayu Kelapa}

UD Sedana Merta adalah perusahaan kayu yang berada di dekat Desa Selumbung yaitu Desa Ngis Kecamatan Manggis Kabupaten Karangasem. Nilai potensi kayu kelapa pada perusahaan ini dijadikan acuan untuk memperoleh angka-angka yang diperlukan. Pada perusahaan ini, kayu kelapa dalam yang dapat dijadikan kayu balok (seseh) memiliki diameter $50 \mathrm{~cm}$ dengan tinggi batang pohon kelapa 20 meter. Allorerung (1990) mengemukakan bahwa produksi kelapa setelah umur 50 tahun akan menurun sejalan dengan bertambahnya umur tanaman, namun setelah personal komunikasi terhadap pemilik UD. Sedana Merta, mengatakan bahwa umur tanaman kelapa yang batangnya dapat dijadikan kayu balok adalah 100 tahun. Asumsi tersebut diperkirakan akan menghasilkan kayu balok yang kuat, karena semakin meningkat umur pohon, maka akan semakin kuat batang pohon kelapa tersebut. Jika umur pohon masih muda sudah ditebang, maka kayu kelapa akan cepat rapuh. 
Tinggi batang pohon kelapa 20 meter dapat dibagi menjadi tiga kualitas, yaitu kualitas I dengan tinggi batang 8 meter, kualitas II dengan tinggi batang 8 meter, dan kualitas III dengan tinggi batang 4 meter. Pada kualitas I, II, dan III didapatkan nilai jual masing-masing sebesar Rp 800.000,00; Rp 640.000,00; dan $\mathrm{Rp} 160.000,00$. Jadi, dalam satu pohon kelapa yang dapat dijadikan kayu balok mendapatkan nilai jual $\mathrm{Rp} 1.600 .000,00$ dengan volume $0,48 \mathrm{~m}^{3}$. Biaya tebang dan angkut kayu sebesar Rp 350.000/pohon. Berdasarkan nilai-nilai tersebut dapat diperhitungkan ke dalam bentuk satuan meter kubik pada Tabel 1 .

Tabel 1. Analisis Nilai Potensi Kayu Kelapa Dalam di Desa Selumbung, Kecamatan Manggis, Kabupaten Karangasem

\begin{tabular}{|c|c|c|c|}
\hline No & Uraian & Notasi & Nilai \\
\hline 1 & $\begin{array}{l}\text { Luas kebun } \\
\text { kelapa (ha) }\end{array}$ & $a$ & 330,13 \\
\hline 2 & $\begin{array}{l}\text { Asumsi } \\
\text { umur pohon } \\
\text { kelapa } \\
\text { (tahun) }\end{array}$ & $\mathrm{b}$ & 100,00 \\
\hline 3 & $\begin{array}{l}\text { Rata-rata } \\
\text { jumlah } \\
\text { pohon kelapa } \\
\text { per ha } \\
\text { (pohon) }\end{array}$ & $\mathrm{c}$ & 114,00 \\
\hline 4 & $\begin{array}{l}\text { Potensi kayu } \\
\text { per pohon } \\
\left(\mathrm{m}^{3}\right)\end{array}$ & d & 0,48 \\
\hline 5 & $\begin{array}{l}\text { Harga kayu } \\
\text { (Rp/pohon) }\end{array}$ & $\mathrm{e}$ & $1.600 .000,00$ \\
\hline 6 & $\begin{array}{l}\text { Biaya tebang } \\
\text { dan angkut } \\
\text { (Rp/pohon) }\end{array}$ & $\mathrm{f}$ & $350.000,00$ \\
\hline 7 & $\begin{array}{l}\text { Potensi kayu } \\
\text { per ha }\left(\mathrm{m}^{3}\right)\end{array}$ & $\begin{array}{c}g=c x \\
d\end{array}$ & 54,72 \\
\hline 8 & $\begin{array}{l}\text { Potensi kayu } \\
\text { kelapa } \\
\text { komersil } \\
\left(\mathrm{m}^{3}\right)\end{array}$ & $\begin{array}{c}\mathrm{h}=\mathrm{a} x \\
\mathrm{~g}\end{array}$ & $18.064,71$ \\
\hline 9 & $\begin{array}{l}\text { Harga kayu } \\
\left(\mathrm{Rp} / \mathrm{m}^{3}\right)\end{array}$ & $\mathrm{i}=\mathrm{e} / \mathrm{d}$ & $3.333 .333,33$ \\
\hline 10 & $\begin{array}{l}\text { Nilai kotor } \\
\text { manfaat } \\
\text { kayu kelapa } \\
\text { (Rp) }\end{array}$ & $\underset{\mathrm{i}}{\mathrm{j}=\mathrm{h} x}$ & $60.215 .712 .000,00$ \\
\hline 11 & $\begin{array}{l}\text { Biaya tebang } \\
\text { dan angkut } \\
\left(\mathrm{Rp} / \mathrm{m}^{3}\right)\end{array}$ & $k=f / d$ & $729.166,67$ \\
\hline 12 & $\begin{array}{l}\text { Total biaya } \\
\text { (Rp) }\end{array}$ & $\begin{array}{c}1=\mathrm{h} x \\
\mathrm{k}\end{array}$ & $13.172 .187 .000,00$ \\
\hline 13 & $\begin{array}{l}\text { Nilai bersih } \\
\text { manfaat } \\
\text { kayu kelapa } \\
(\mathrm{Rp})\end{array}$ & $\underset{1}{m=j}-$ & $47.043 .525 .000,00$ \\
\hline 14 & $\begin{array}{l}\text { Nilai potensi } \\
\text { kayu } \\
\text { (Rp/tahun) }\end{array}$ & $\begin{array}{l}\mathrm{n}= \\
\mathrm{m} / \mathrm{b}\end{array}$ & $470.435 .250,00$ \\
\hline
\end{tabular}

Berdasarkan Tabel 1, Nilai manfaat bersih kayu kelapa ini diperoleh sebesar $\mathrm{Rp}$ 47.043.525.000,00. Nilai ini diperoleh dari pengurangan dari nilai kotor manfaat kayu dengan total biaya yang dikeluarkan. Jadi nilai potensi kayu kelapa di Perkebunan Kelapa Desa Selumbung menghasilkan $\mathrm{Rp}$ 470.435.250,00/tahun, nilai ini diperoleh dari pembagian nilai manfaat bersih kayu kelapa dibagi dengan umur pohon kelapa yaitu 100 tahun. Hal ini berarti jika kayu kelapa tersebut ditebang secara keseluruhan seluas 330,13 ha di Desa Selumbung, maka hanya memperoleh keuntungan Rp 470.435.250,00 per tahun.

\section{Nilai Ekonomi Total Perkebunan Kelapa}

Perkebunan Kelapa di Desa Selumbung sangat dimanfaatkan oleh masyarakat baik secara langsung maupun tidak langsung. Berdasarkan observasi dan wawancara dengan responden, maka dapat diidentifikasi nilai pemanfaatan kebun kelapa, yaitu sebagai berikut.

\section{Nilai manfaat langsung perkebunan kelapa}

Manfaat langsung dari pohon kelapa ini ada daun kelapa tua (slepan), daun kelapa muda (janur), dan buah kelapanya. Nilai dari slepan di hitung berdasarkan banyaknya jumlah plapah, janur berdasarkan jumlah helai, sedangkan buah di hitung berdasarkan jumlah butir. Nilai manfaat langsung yang diperoleh adalah $\mathrm{Rp}$ 15.572.472,00.

Nilai manfaat buah kelapa menunjukkan persentase tertinggi sebesar Rp 14.602.500,00 atau $93,77 \%$ dari keseluruhan nilai manfaat langsung. Hal ini berarti buah kelapa sangat berpengaruh terhadap pendapatan petani. Para petani sebagian besar menggantungkan hidupnya pada penghasilan dari buah kelapa ini. Allorerung (1990) mengemukakan bahwa produksi kelapa setelah umur 50 tahun akan menurun sejalan dengan bertambahnya umur tanaman. Rata-rata usia tanaman kelapa pada saat penelittian sekitar 70 tahun. Dengan adanya pendapat dari Allorerung (1990) tersebut bahwa sebenarnya umur tanaman kelapa sekarang sudah memasuki umur ekonomis, namun produksi kelapa masih mampu menutupi hasil dari nilai potensi kayu tersebut.

2. Nilai manfaat tidak langsung perkebunan kelapa

Manfaat tidak langsung adalah nilai manfaat dari suatu sumberdaya pohon kelapa yang dimanfaatkan secara tidak langsung oleh masyarakat. Manfaat tidak langsung pohon kelapa ini dapat berupa manfaat fisik yaitu sebagai penyangga bukit-bukit agar tidak terjadi longsor pada saat musim hujan pada daerah yang ditanamani pohon kelapa. Dalam hal ini 
diasumsikan dengan kondisi lahan gundul. Daerah tersebut supaya tidak terjadi longsor, maka perlu dilakukan reboisasi. Reboisasi adalah upaya penanaman jenis pohon hutan pada kawasan hutan rusak seperti lahan kosong, alangalang, atau semak belukar untuk mengembalikan fungsi hutan (PP Nomor 24, 2010). Selain sebagai penahan longsor, reboisasi juga dapat bermanfaat mengembalikan fungsi hutan yaitu sebagai paru-paru dunia, artinya hutan dapat menyerap gas karbon dioksida yang berbahaya bagi manusia dan menghasilkan gas oksigen yang sangat diperlukan manusia (Alvian, 2015). Investasi reboisasi ini sebesar Rp 10.475.000,00.

Nilai reboisasi penanaman intensif wilayah Bali berdasarkan Peraturan Direktur Jenderal Bina Pengelolaan Daerah Aliran Sungai dan Perhutanan Sosial tentang ancar-ancar Harga Satuan Pokok Kegiatan (HSPK) Bidang PDAS PS Tahun 2014 memliki persentase tertinggi yaitu sebesar Rp 7.133.000,00 atau 68,09\% dari keseluruhan manfaat tidak langsung tersebut. Hal ini diperoleh dari pembiayaan tenaga kerja, biaya pembelian bibit dan lain sebagainya. Pada uraian pemeliharaan tahun pertama dan kedua hanya merupakan sebagai tambahan biaya setelah dilakukan penanaman. Nilai tersebut dihitung dalam satu hektar.

\section{Nilai Manfaat Pilihan Perkebunan Kelapa}

Nilai keanekaragaman hayati yang ada pada perkebunan kelapa di Desa Selumbung ini adalah tanaman pisang (kladi, sumatra, daun pisang batu, gedang saba), kakao, wani, durian, dan nangka. Kakao memberikan kontribusi/penerimaan tertinggi sebesar Rp 3.240.180,00 atau 34,11\% dari keseluruhan nilai manfaat pilihan, diikuti dengan penerimaan pisang gedang saba sebesar Rp 3.079.492,00 atau $32,42 \%$. Hal tersebut juga terlihat pada jumlah pohon yang ditanam lebih banyak dibandingkan tanaman lainnya. Kontribusi/penerimaan terendah diperoleh dari buah wani sebesar Rp 150.500,00 atau 1,58\% yang terlihat pada rata-rata jumlah pohon yang dimiliki hanya satu pohon/ha.

\section{Nilai Manfaat Keberadaan Perkebunan Kelapa}

Nilai Manfaat Keberadaan adalah nilai kepedulian seseorang akan keberadaan suatu sumberdaya alam. Nilai tersebut menggunakan pendekatan WTP (Willingness to Pay) yaitu kesediaan petani membayar agar tetap mempertahankan perkebunan kelapa. Mempertahankan perkebunan kelapa artinya tanaman kelapa masih bisa difungsikan, sehingga diperlukan suatu pemupukan agar pohon kelapa dapat bertahan dan tidak ditebang.
Dalam hal ini, diasumsikan petani dengan membeli pupuk organik yang terdapat pada simantri setempat. Sistem pertanian terintegrasi (simantri) merupakan salah satu program unggulan daerah Pemerintah Provinsi Bali untuk peningkatan peran sektor pertanian mendukung Bali Mandara. Konsep Simantri selain memberdayakan hubungan fungsi masingmasing kegiatan juga mendorong pada pemanfaatan limbah pertanian dan ternak menjadi komponen pendukung integrasi di tingkat kelompok simantri. Kegiatan ini berorientasi pada usaha pertanian tanpa limbah (zero waste) dan menghasilkan $4 \mathrm{~F}$ (food, feed, fertilizer, dan fuel). Beberapa hasil penelitian terkait dengan simantri di Provinsi Bali menunjukkan bahwa pelaksanaan pola integrasi tanaman ternak di lokasi simantri telah memberikan dampak pada tumbuhnya kegiatan usaha kelompok, lapangan pekerjaan, pemenuhan kebutuhan pangan, pakan, pupuk dan pestisida organik serta biogas di tingkat kelompok maupun untuk tujuan komersial melalui dukungan kebijakan pemda setempat (Iwan, 2014).

Nilai kemauan petani dalam membeli pupuk organik adalah Rp 727.662,00/ha. Nilai tersebut diperoleh dari rata-rata kemauan petani dalam membeli pupuk organik sebesar Rp 6.383,00 per pohon dikalikan dengan rata-rata jumlah pohon per ha yaitu 114 pohon. Harga pupuk organik pada simantri setempat adalah Rp 800/kg. Pembelian pupuk terendah hanya dua $\mathrm{kg} / \mathrm{tahun}$ untuk satu pohon. hal ini disebabkan oleh petani tersebut hanya sebagai penggarap sedangkan produksi yang harus tersetor lebih banyak ke pemilik.

\section{Nilai Ekonomi Total Perkebunan Kelapa}

Nilai ekonomi total dari perkebunan kelapa ini merupakan penjumlahan dari nilai manfaat langsung, nilai manfaat tidak langsung, nilai manfaat pilihan, dan nilai manfaat keberadaan yang telah diidentifikasikan dan dikuantifikasi selain manfaat dari potensi kayu kelapa.

Nilai manfaat langsung memiliki persentase terbesar yaitu $42,93 \%$ atau $\mathrm{Rp}$ 5.140.940.181,36, hal ini berarti bahwa manfaat pohon kelapa tersebut sangat mempengaruhi pendapatan petani, sehingga penting untuk dipertahankan. Namun, persentase terendah berada pada nilai manfaat keberadaan hanya sebesar 2\% atau $\mathrm{Rp}$ 240.223.056,06, hal ini berarti bahwa keberanian petani dalam membeli pupuk organik yang banyak masih kurang demi meningkatkan kesuburan tanah dan meningkatkan produktivitas. Walaupun demikian, tanaman kelapa ini tetap mampu berproduksi tanpa harus dilakukan pemupukan. 
Dengan diperolehnya nilai ekonomi total sebesar Rp 36.274.752,00/ha dalam satu tahun, maka untuk keseluruhan kebun kelapa di Desa Selumbung adalah sebesar Rp 11.975.383.877,76 dalam satu tahun dengan luas kebun kelapa 330,13 ha. Hal ini serupa dengan penelitian yang dilakukan Ria (2014) dengan menggunakan analisis nilai ekonomi total dengan empat nilai yaitu (manfaat langsung, tidak langsung, pilihan, dan keberadaan), namun pada penelitian tersebut mendapatkan nilai sebesar Rp 10.530.519.419,00/tahun dengan luas 700 hektar.

Nilai manfaat langsung memperoleh persentase tertinggi dibandingkan dengan nilai manfaat lainnya, hal ini berbeda dengan penelitian yang dilakukan Ria (2014) dan Benu (2011) di mana pada penelitian tersebut menunjukkan bahwa manfaat tidak langsung memperoleh persentase terbesar yang masing-masing nilainya sebesar $81,17 \%$ atau $\mathrm{Rp}$ 8.915.036.479,00 per tahun dan $97,99 \%$ atau Rp 10.671.627.482,00 per tahun. Hal ini disebabkan pada penelitian tersebut menyangkut tentang fungsi hutan mangrove, yang memiliki nilai intangible yang lebih tinggi, sedangkan pada penelitian ini lebih mengutamakan nilai manfaat langsung dari pohon kelapa tersebut karena tiap saat menghasilkan nilai.

\section{SIMPULAN DAN SARAN}

\section{Simpulan}

Berdasarkan penelitian dan hasil analisis yang telah dilakukan dapat disimpulkan berbagai simpulan yaitu sebagai berikut.

1. Nilai Potensi kayu kelapa bila ditebang secara keseluruhan memperoleh nilai sebesar Rp 470.435.250,00/tahun. Nilai tersebut diperoleh dari pembagian nilai manfaat bersih kayu kelapa sebesar Rp 47.043.525.000,00 dibagi dengan umur pohon kelapa yaitu 100 tahun.

2. Nilai ekonomi total pada penelitian ini dengan luas 330,13 ha sebesar

Rp 11.975.383.877,76/tahun. Nilai ini diperoleh dari penjumlahan nilai manfaat langsung sebesar Rp 5.140.940.181,36, nilai manfaat tidak langsung sebesar Rp 3.458.111.750,00, nilai manfaat pilihan sebesar Rp 3.136.108.890,34, dan nilai manfaat keberadaan sebesar Rp 240.223.056,06. Dari keempat nilai manfaat tersebut, nilai manfaat langsung memiliki potensi terbesar, oleh sebab itu manfaat langsung dari tanaman kelapa sangat penting untuk selalu diperhatikan.

3. Jika kebun kelapa ini dipertahankan, maka keuntungan akan 25,5 kali lebih besar dibandingkan harus menebang pohon kelapa dalam secara keseluruhan.

\section{Saran}

Berdasarkan penelitian dan hasil analisis tersebut, akan direkomendasikan beberapa saran yaitu.

1. Kepada Petani di Desa Selumbung:

Perkebunan kelapa di Desa Selumbung mempunyai manfaat dan fungsi yang penting sebagai sumber daya ekonomi bagi kehidupan masyarakat yang berada disekitarnya. Oleh karena itu, keberadaan tanaman kelapa dan tanaman lainnya yang berada pada perkebunan tersebut harus tetap bertahan dan terpelihara serta dilakukannya pemupukan terhadap tanaman kelapa sehingga akan menghasilkan produksi yang lebih optimal.

2. Kepada Pemerintah

Perkebunan kelapa di Desa Selumbung cukup berpotensi untuk terus dilakukan pembinaan kepada petani, seperti melakukan penyuluhan dan pemberian pupuk agar buah kelapa menghasilkan produksi yang optimal.

\section{UCAPAN TERIMA KASIH}

Melalui e-jurnal ini saya mengucapkan terima kasih kepada Perbekel Desa Selumbung, para petani sampel, dan Dinas yang terkait pada penelitian ini, sehingga saya dapat menyelesaikan e-jurnal ini dengan baik.

\section{DAFTAR PUSTAKA}

Alam, S., Supratman, dan Alif, M. 2009. Ekonomi Sumberdaya Hutan. Buku Ajar.

Laboratorium Kebijakan dan

Kewirausahaan Kehutanan. Universitas Hasanuddin, Makasar.

Alvian,R. 2015. Pentingnya 7 Fungsi Hutan Bagi Kehidupan. [Artikel on-line]. http://ipemanasanglobal.blogspot.com/201 5/01/pentingnya-7-fungsi-hutan-bagikehidupan.html. Diunduh pada 4 Januari 2017.

[UPTD]. Unit Pelaksana Teknis Dinas Kehutanan dan Perkebunan Kabupaten Karangasem. . 2015. Data statistik tanaman kelapa di Desa Selumbung tahun 2015.

[Ditjen Bina PDAS PS]. Direktur Jenderal Bina Pengelolaan daerah Aliran Sungai dan Perhutanan Sosial: Kementerian Kehutanan. 2014. Ancar-ancar Harga Satuan Pokok Kegiatan (HSPK) Bidang PDAS PS Tahun 2014. Peraturan Direktur Jenderal Bina Pengelolaan daerah Aliran Sungai dan Perhutanan Sosial: Kementerian Kehutanan. 
Sepel, IN. 2011. Profil Tingkat Perkembangan Pembangunan 2 Tahun Terakhir (20092010). Desa Selumbung. Provinsi Bali.

[BPTP]. Balai Pengkajian Teknologi Pertanian Propinsi Bali. 2006. Laporan Akhir Teknologi Pasca Panen Kelapa.

[Disbun]. Dinas Perkebunan Provinsi Bali: Denpasar. 2016. Statistik Perkebunan Bali 2015.

Iqbal. 2014. Nilai Ekonomi Total Sumberdaya Bambu (Bambuseae Sp.) Di Kecamatan Sajira, Kabupaten Lebak, Banten: Pusat Penelitian dan Pengembangan Keteknikan Kehutanan \& Pengolahan Hasil Hutan

Fauzi A. 1999. Teknik Valuasi Ekosistem Mangrove. Bahan Pelatihan Management for Mangrove Forest (Rehabilitation). Bogor. Oktober 1999.

Peraturan Pemerintah Republik Indonesia Nomor 24 Tahun 2010. Penggunaan Kawasan Hutan. Jakarta

Ria. 2014. Nilai Ekonomi Total Hutan Mangrove Desa Margasari Kecamatan Labuhan Maringgai Kabupaten Lampung Timur: Jurusan Kehutanan Fakultas Pertanian Universitas Lampung.

Benu. 2011. Valuasi Ekonomi Sumberdaya Hutan Mangrove Di Desa Palaes, Kecamatan Likupang Barat, Kabupaten Minahasa Utara: Sulawesi Utara.

Fauzi A. 1999. Teknik Valuasi Ekosistem Mangrove. Bahan Pelatihan Management for Mangrove Forest (Rehabilitation). Bogor. Oktober 1999. 